Departamento de Psicologia Escolar e do Desenvolvimento - PED

Programa de Pós-Graduação em Processos de Desenvolvimento Humano e Saúde PGPDS

CURSO DE ESPECIALIZAÇÃO EM DESENVOLVIMENTO HUMANO, EDUCAÇÃO E INCLUSÃO ESCOLAR

\title{
O USO PEDAGÓGICO DO LÚDICO NO PROCESSO DE INCLUSÃO ESCOLAR DA CRIANÇA ESPECIAL
}

\author{
MARA JHOSY PAULA QUEIROZ
}

ORIENTADORA: RUTE NOGUEIRA DE MORAIS BICALHO 
Departamento de Psicologia Escolar e do Desenvolvimento - PED

Programa de Pós-Graduação em Processos de Desenvolvimento Humano e Saúde PGPDS

\section{O USO PEDAGÓGICO DO LÚDICO NO PROCESSO DE INCLUSÃO ESCOLAR DA CRIANÇA ESPECIAL}

Monografia apresentada ao Curso de Especialização e

Desenvolvimento Humano, Educação e Inclusão Escolar da Faculdade UAB/UNB.

Orientadora: Rute Nogueira de Morais Bicalho

BRASÍLIA, 2011 


\section{O USO PEDAGÓGICO DO LÚDICO NO PROCESSO DE INCLUSÃO ESCOLAR DA CRIANÇA ESPECIAL}

Monografia aprovada como requisito parcial para obtenção do grau de Especialista do Curso de Especialização em Desenvolvimento Humano, Educação e Inclusão Escolar UAB/UnB. Apresentação ocorrida em $/ 2011$

RUTE NOGUEIRA DE MORAIS BICALHO - ORIENTADORA

\section{EXAMINADOR}

MARA JHOSY PAULA QUEIROZ

BRASÍLIA/ 2011 


\section{DEDICATÓRIA}

Aos meus pais, meu esposo e companheiro Georges, ao irmão Mario

Janone, a amiga Gildete Rainha e aos professores que fizeram parte

desta pesquisa. 


\section{AGRADECIMENTOS}

A Deus pelo seu infinito amor, misericórdia, cuidado e sustento todos os dias;

À $U A B / U n B$ que ofereceu esse curso de especialização em Desenvolvimento Humano, Educação e Inclusão Escolar, oportunizando uma formação de qualidade tão importante no contexto escolar;

À minha orientadora, Rute Nogueira de Morais Bicalho pelo constante apoio e incentivo, que com tanto zelo me orientou na realização deste trabalho;

Aos colegas do curso que me proporcionaram aprendizado diário nos fóruns com conhecimentos e relatos de experiências tão marcantes e motivadoras;

Aos participantes desta pesquisa que compartilharam vivências tão significativas para o enriquecimento desse trabalho e por terem demonstrado através de suas falas tanto carinho e dedicação no trabalho com crianças especiais;

Ao meu irmão Mário Janone que foi um meu grande incentivador na realização e conclusão deste curso. 


\section{RESUMO}

Este trabalho trata de um estudo sobre a utilização do lúdico como recurso pedagógico no processo de inclusão escolar da criança especial a partir da percepção dos professores que atuam na sala de recurso. De orientação qualitativa, foram feitas entrevistas com dois professores de uma escola localizada no Distrito Federal. A partir das falas dos participantes emergiram três categorias: 1 - percepção dos professores sobre a inclusão e o aluno especial; 2 - o uso do lúdico como estratégia pedagógica; e 3 - o desenvolvimento do aluno com necessidades educativas especiais a partir das atividades lúdicas. Os dados coletados indicam que os professores da sala de recurso utilizam o lúdico como estratégia pedagógica para alcançar os objetivos acadêmicos propostos com seus alunos. As atividades lúdicas são utilizadas de forma livre, individual ou em grupo, as quais colocam-se como importantes recursos pedagógicos por apresentar ganhos nas áreas cognitiva, afetiva, social e motora, promovendo desta forma o processo de inclusão da criança especial no ensino regular.

Palavras-chave: Inclusão escolar. Atividades Lúdicas. Sala de recursos. Processo ensino-aprendizagem. 


\begin{abstract}
The aim of this work is about a study on the use of playful for pedagogic resources. From the perception of the teachers who act in the resource room, this study would benefit all type of scholar inclusion process for Childs with special needs. From a qualitative direction, interviews where made using two school teachers located in the District Columbus area to sustain current research. Thru participants' interviews three categories appeared: $1-$ Teachers's perception about inclusion and Childs with special needs; 2 - Use of playful as a pedagogic strategy and 3 - The development of Childs with special educational needs thru special playful activities. The data collected indicate that teachers of the resource room use the playful as a pedagogic strategy to reach the academic objectives proposed with their students. The playful activities are of free use, into an individual form or in group, which place themselves like important pedagogic resources because of presenting profits in the cognitive, affectionate, social areas and mobility. This would promote the process the inclusion of Childs with special needs in regular teaching routine.
\end{abstract}

Keywords: Scholar inclusion, Playful activities, resource room, teaching-learning process 


\section{SUMÁRIO}

1. APRESENTAÇÃ

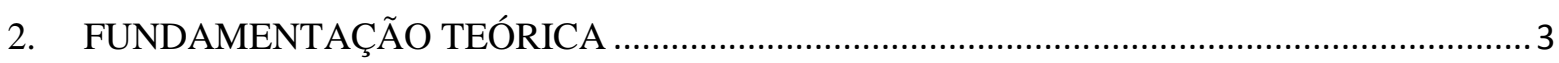

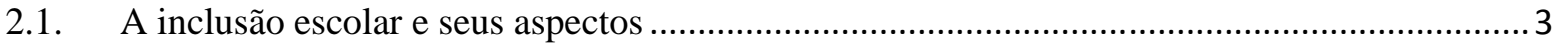

2.2. O papel da escola e o trabalho pedagógico ..........................................................................

2.3. A relação da criança com as atividades lúdicas .................................................................... 8

2.4. O lúdico e sua relação com a aprendizagem .....................................................................13

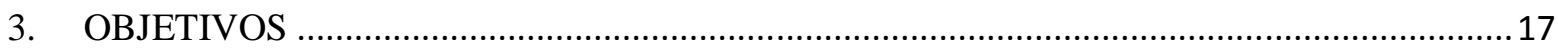

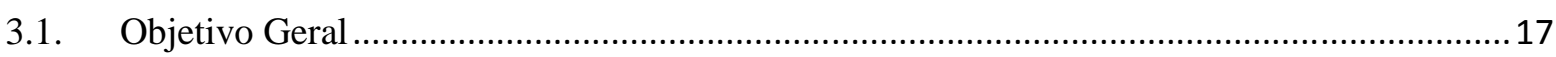

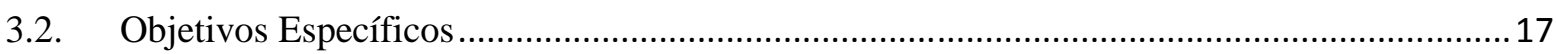

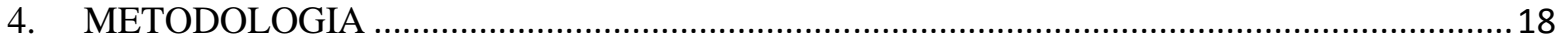

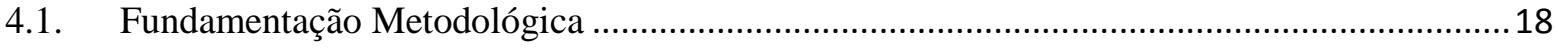

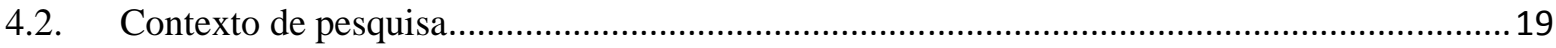

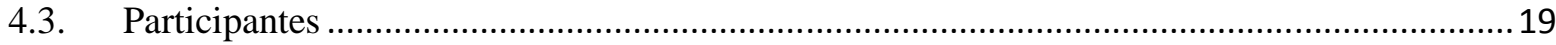

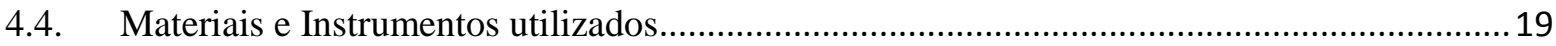

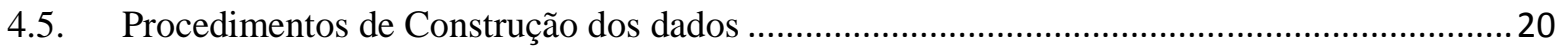

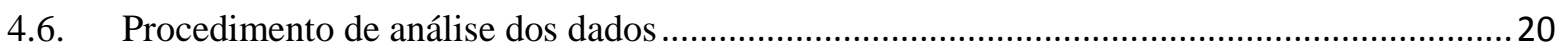

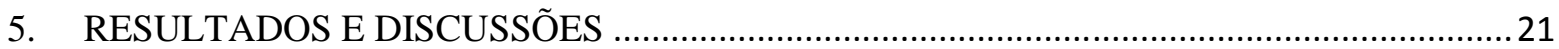

5.1. Categoria 1 - Percepção dos professores sobre a inclusão e o aluno especial..........................21

5.2. Categoria 2 - o uso do lúdico como estratégia pedagógica.....................................................23

5.3. Categoria 3 - o desenvolvimento do aluno com NEE a partir das atividades lúdicas ............28

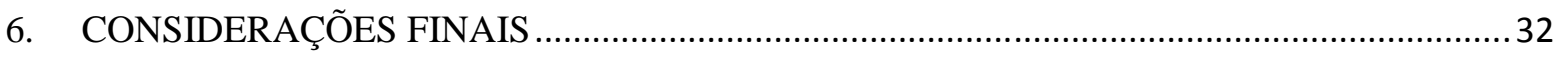

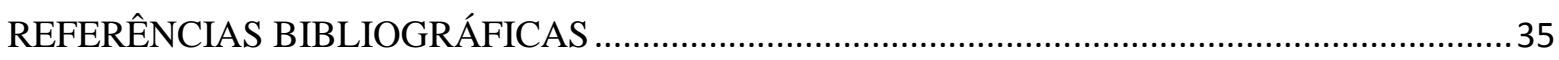

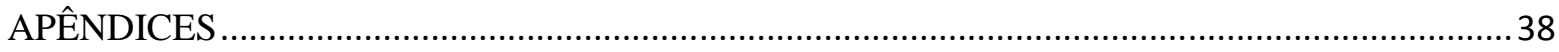

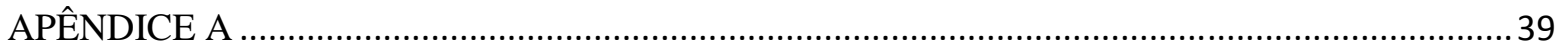

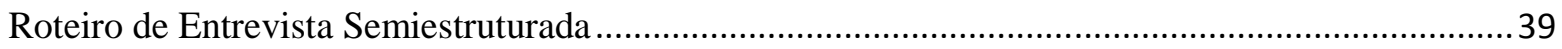

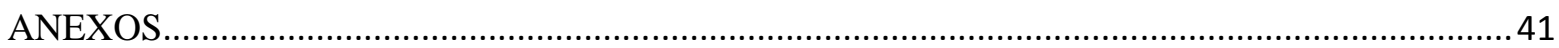

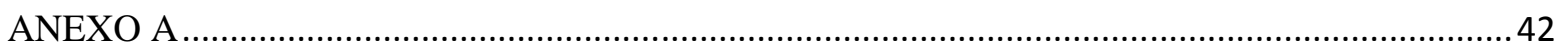

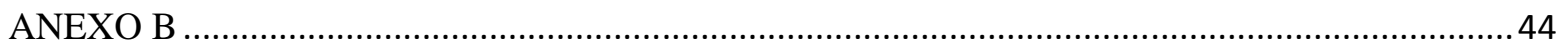




\section{APRESENTAÇÃO}

Muito tem se falado sobre o processo de inclusão e não tem ninguém mais interessado em ter seu espaço garantido em escolas de ensino regular inclusas com propósitos bem definidos, oferecendo e atendendo com dignidade as suas necessidades com garantias de locais adaptados, acompanhamento pedagógico especializado e que esteja coberto de direitos legais do que o aluno com necessidades educacionais especiais. Esta sim é o sujeito principal desse processo e é por ela que muito tem se falado e buscado ações para que isso aconteça de fato.

Documentos reconhecidos nacionalmente e até internacionalmente apontam diretrizes que favorecem uma educação em que todos estejam incluídos. $\mathrm{O}$ documento que marcou a história em favor da inclusão fortalecendo essa ideia em vários países e no Brasil foi a Declaração de Salamanca assinado em 1994 que apontam caminhos para uma educação em que todos os alunos com necessidades educativas especiais sejam inclusivas em escolas regulares e que possam ter uma educação de qualidade. A LDB: Lei de Diretrizes e Bases da Educação e Plano Nacional de Educação também garantem esse direito.

Uma escola de qualidade que atenda a criança nas suas necessidades deve conter, dentro de sua estratégia de planejamento, formas estabelecidas de processos de ensino aprendizagem que conte com inúmeras possibilidades metodológicas de recursos pedagógicos. E a ação pedagógica não deve se limitar apenas ao ensinar e aprender, ela deve estar intimamente ligada ao descobrir, ao fazer e compreender todo o conjunto que envolve o aprendizado de uma criança.

Um recurso que deve ser utilizado como estratégia de planejamento de professores que trabalham com processo de inclusão escolar do aluno com necessidades educacionais especiais são as atividades lúdicas que favorecem o desenvolvimento da criança nos seus mais diversos aspectos: cognitivo, social, afetivo e motor, e sua utilização torna-se uma ferramenta incentivadora e estimuladora das várias atividades exercidas, no seu desenvolvimento global e em sua aprendizagem tornando-a mais prazerosa e interessante para a criança. 
Atividades recreativas na escola são de alto valor para a educação social, pois facilitam a convivência entre os alunos e professores desenvolvendo o verdadeiro sentido da vida em comunidade. Dessa forma, as atividades realizadas nas interações sociais, promovem a internalização, a aprendizagem e o desenvolvimento.

Assim a pesquisa busca compreender, a partir da percepção de professores que atuam na sala de recurso, como ocorre o uso pedagógico das atividades lúdicas para o processo de inclusão do aluno com necessidades educacionais especiais na Educação infantil.

Para alcançar os objetivos propostos, pretende-se falar sobre o uso lúdico como estratégia pedagógica do professor da sala de recurso para o processo de inclusão do aluno com necessidade educativas especiais no ensino regular. 


\section{FUNDAMENTAÇÃO TEÓRICA}

\subsection{A inclusão escolar e seus aspectos}

A visibilidade da pessoa com necessidades especiais na sociedade ocorre quando as próprias pessoas o compreendem como cidadão, com direitos, deveres e conquistas. Mais do que isso, a valorização do espaço, seja na mídia, no trabalho, nas artes, nos esportes, em todas as dimensões da sociedade coopera para a valorização dessa pessoa, de sua luta, da compreensão de suas limitações e no esforço de proporcionar acessibilidades necessárias para o pleno exercício de sua cidadania.

A inclusão de pessoas com necessidades especiais enquanto cidadãos, com seus respectivos direitos e deveres de participação e contribuição social, entra no contexto das discussões que se referem às necessidades educacionais especiais na rede regular de ensino, cada vez mais em evidência. A legitimidade do movimento em favor da inclusão escolar se faz quando na própria história desse movimento existe o debate e luta pela qualidade, direito e acessibilidade à educação de crianças e jovens com necessidades especiais (MENDES, 2006).

A Educação Inclusiva é "a prática da inclusão de todos - independentemente do seu talento, deficiência, origem socioeconômica ou cultural - em escolas e salas de aula provedoras, onde as necessidades desses alunos sejam satisfeitas". (STAINBACK \& STAINBACK, 1999, apud MARTINS, 2006) Uma escola inclusiva pressupõe uma educação de qualidade oferecida conjuntamente, tanto para alunos ditos normais, como para os alunos com necessidades educativas especiais (ANEE) em classes comuns do ensino regular sendo desenvolvido um trabalho pedagógico que sirva a todos indiscriminadamente (AGUIAR, 2005).

A Declaração de Salamanca (1994) foi um marco histórico a favor da inclusão, pois apontam diretrizes que favoreçam uma educação em que todos estejam incluídos em escolas regulares, e esse documento diz que o princípio fundamental da escola inclusiva é o de que todas as crianças deveriam aprender juntas, independentemente de quaisquer dificuldades ou diferenças que possam ter, sejam de origens física, intelectual, social, emocional, linguística ou outras. 
As escolas inclusivas devem reconhecer e responder às diversas necessidades de seus alunos, acomodando tanto estilos como ritmos diferentes de aprendizagem e assegurando uma educação de qualidade a todos através de currículo apropriado, modificações organizacionais, estratégias de ensino, uso de recursos e parcerias com a comunidade. Para Stainback (1999), a competência da comunidade escolar em dar apoio aos alunos com necessidades educacionais especiais na escola; em uma ideia de cooperação mútua, cria o desenvolvimento de um clima de respeito, interesse e responsabilidade para com o outro e passa a ser consequência de um hábito onde todos reconhecem o outro como parte integrante e importante do grupo, tendo em vista que a partir desse pressuposto todos são chamados a ajudar e contribuir para o bem estar coletivo.

O processo de integração implica em ações interativas. Para que essas ocorram de modo efetivo, recíproca e constante, é fundamental a existência de interesses e objetivos comuns, o que pressupõe comunicação, identidade social, assimilação e participação dos alunos com necessidades educativas especiais na rotina escolar. (ANGELUCCI, 2002)

Mendes (2006) propõe uma reflexão acerca das práticas e políticas públicas voltadas para a inclusão escolar, assim como questionar que práticas e conhecimentos teóricos que fundamentam essa prática para uma inclusão escolar de qualidade.

Atualmente, o aluno incluído é aquele considerado com necessidades educativas especiais, tendo um programa de ensino que deve ser alterado para atender suas necessidades particulares, pois apresentam características próprias que o diferem da grande maioria da população, no que diz respeito ao domínio das aprendizagens curriculares correspondentes a sua faixa etária. A LDB: Lei de Diretrizes e Bases da Educação (1996) garante que a educação especial é uma modalidade de educação escolar e seu atendimento ocorre preferencialmente na rede regular de ensino para alunos com necessidades educativas especiais.

A Declaração de Salamanca (1994) instituiu como princípio fundamental da escola inclusiva o aprendizado coletivo, independente de quaisquer dificuldades ou diferenças que possam ter juntas, cabendo à escola inclusiva o desafio de responder satisfatoriamente às necessidades educacionais dos alunos incluídos. 
A criança com necessidades educacionais especiais, ao ser inclusa, deve estar sendo acompanhada sistematicamente onde esteja, tendo a sua disposição condições pedagógicas, educacionais e terapêuticas para que ela aprenda algo, ou para que ela se integre com seus colegas com menos conflito e com mais segurança.

O processo de inclusão implica em ações interativas. Para que essas ocorram de modo efetivo, recíproca e constante, é fundamental a existência de interesses e objetivos comuns, o que pressupõe comunicação, identidade social, assimilação e participação dos alunos com necessidades educacionais especiais na rotina escolar.

\subsection{O papel da escola e o trabalho pedagógico}

Poderíamos dizer que a função pedagógica tem como objetivo tomar a realidade tendo como ponto de partida os conhecimentos infantis na busca de ampliá-los através de um significado concreto para a vida das crianças e que, simultaneamente, asseguram a aquisição de novos conhecimentos e uma aprendizagem que seja prazerosa, tendo ambiente escolar um lugar propício para o desenvolvimento global da criança.

Vygotsky (1998) percebe que o aprendizado das crianças começa muito antes delas frequentarem a escola, ou seja, qualquer situação de aprendizado em que a criança vivencia em si já traz uma experiência, uma vivência, uma história prévia desse aprendizado. Contudo Vygotsky (1998) vê no aprendizado escolar sua relevância, visto que produz algo novo, novas experiências e aprendizados no desenvolvimento da criança. "Aprendizado e desenvolvimento estão inter-relacionados desde o primeiro dia de vida da criança" (VYGOTSKI, 1998, p.110). Dessa forma o papel da escola pode ser entendido como o de valorizar os conhecimentos que as crianças possuem e garantir a aquisição de novos conhecimentos.

Machado (1991), tentando encontrar uma maneira de estabelecer algumas diretrizes que obedecessem à forma como os interesses e atividades da criança se organizam a partir do seu desenvolvimento chegou aos seguintes pontos:

1. Autonomia: a criança se empenha em conquistar sua independência em relação ao adulto; 
2. Rotina, regras, limites: a criança atravessa uma fase de adaptação na passagem do ambiente familiar para o escolar, passando a conviver com outros ritmos, possibilidades e limitações;

3. Interações: a criança x o outro; a criança x si própria; a criança x o mundo;

4. Linguagem: a criança se expressa e representa de diversas formas seus pensamento, conhecimentos, sentimentos.

5. Matemática: ela realiza continuamente jogos e brincadeiras, quando então classifica ordena objetos e materiais, atingindo passo a passo os primeiros indícios de abstração, quantificando, estabelecendo relações, fazendo cálculos.

Assim, pode-se construir a partir dessas diretrizes, ações que permita à criança exercitar sua liberdade, sendo respeitada em suas decisões percebendo as responsabilidades decorrentes de sua escolha tendo professor o papel fundamental de orientar, estimular e desenvolver aspectos positivos para o desenvolvimento da criança sendo este um dos objetivos de sua estratégia pedagógica.

O professor é o agente que fará a intervenção nesse processo de ensino aprendizagem com seu aluno. Arribas (2002) sugere três formas de intervenção do professor: observador, participante e animador: Observador: observa a atitude; Participante: busca criar condições propícias para que os alunos desenvolvam suas habilidades motoras. O professor participante permite um estreitamento da relação professor aluno, onde havendo uma relação de afetividade, favorece uma praticipação maior dos alunos; Animador: permite ao aluno construir um espaço que o permita aprender por meio de uma orientação do professor que busque auxiliá-los e encontar a solução para uma determinada situação-problema.

O papel do professor é também permitir que seu aluno se desenvolva de forma livre e criativa possibilitando momentos de descobertas por si só. Pois, "Mesmo sendo o professor quem faz as propostas e conduz o processo de ensino e aprendizagem, ele deve elaborar sua intevenção de modo que os alunos tenham escolhas a fazer, decisões a tomar, problemas a resolver; assim os alunos podem tornar-se cada vez mais independentes e responsáveis" (PCN, 1997, p.60). 
Nas escolas inclusivas, estratégia pedagógica usada para o desenvolvimento da criança inclusa, deverá ser na área em que ela tem maior dificuldade e este é um dos objetivos principais da escola, e para que isso aconteça além das horas em sala de aula, ela tem direito ao atendimento complementar na sala de recurso em horário contrário de aula. Esse atendimento tem características próprias: "o trabalho desenvolvido na sala de recursos deve partir dos interesses, necessidades e dificuldades de aprendizagem específicas de cada aluno, oferecendo subsídios pedagógicos e contribuindo para a aprendizagem dos conteúdos da classe comum". (ARNAL, 2010, p.3)

\title{
O Ministério da Educação diz que
}

\begin{abstract}
"A iniciativa de implantação de salas de recursos multifuncionais nas escolas públicas de ensino regular responde aos objetivos de uma prática educacional inclusiva que organiza serviços para o atendimento educacional especializado, disponibiliza recursos e promove atividades para desenvolver o potencial de todos os alunos, a sua participação e aprendizagem”. (ME, 2006, p. 12)
\end{abstract}

O trabalho deve ser voltado para as necessidades nas áreas de desenvolvimento cognitivo, motor, social, afetivo e emocional, com vistas a subsidiar os conceitos e conteúdos defasados no processo de aprendizagem para atingir o currículo da classe comum. O trabalho na sala de recurso deve ser diferenciado utilizando-se de estratégias atrativas e diferenciadas e não deve ser comparado como uma aula de reforço que têm objetivos e metodologia totalmente diferente da que é usada na sala de recurso. (ARNAL, 2010)

O professor que trabalha na sala de recurso deve ter algumas atribuições importantes para se trabalhar com aluno incluso, como: atuar de forma colaborativa com o professor da classe comum, promover a inclusão dos seus alunos em todas as atividades da escola, envolver as famílias nas atividades, estar envolvido em todas as ações da escola desenvolvendo uma ação conjunta com os professores de classes comuns no processo de inclusão. (ME, 2006)

Nas salas de recurso o material e os recursos pedagógicos devem ser diversificados para atrair o aluno para que o trabalho não se torne cansativo e desmotivante. Um exemplo de material simples, mas de uma riqueza pelos resultados que são obtidos quando utilizados são os jogos, "É no brinquedo que a criança aprende a agir numa 
esfera cognitiva, ao invés de numa esfera visual externa, dependendo das motivações e tendências íntimas, e não dos incentivos fornecidos pelos objetos externos". (VYGOSTSKI, 1998, p. 126)

\subsection{A relação da criança com as atividades lúdicas}

Ao falar em atividades lúdicas logo associamos a algo prazeroso com sensações que permitem explorar e desabrochar sentimentos e sentidos importantes inerentes ao homem, enfim a tudo que está o desenvolvimento seja ele cognitivo, afetivo, social e motor.

Friedmann (1996), afirma que atividade lúdica envolve de forma mais ampla, os conceitos de jogo, brincadeira e brinquedo assim como Negrine (1994), Baptista da Silva (2003), Biscoli (2005), Vygotsky (1991) também não fazem diferenciação semântica entre jogo e brincadeira (AGUIAR, 2005). Estes autores utilizam ambas as palavras para designar o mesmo comportamento, a atividade lúdica. Segundo Aurélio (2010), esses termos se definem como: jogo - "exercício ou divertimento, passatempo"; brincadeira -“ divertimento"; brinquedo - " objeto destinado a divertir uma criança"; lúdico - "que tem o caráter de jogos, brinquedos e divertimentos".

O hábito de brincar é comum a todas as crianças, seja sozinha ou com amigos. Este hábito é tão presente em nossa cultura e na vida social da criança que se torna uma questão corriqueira como o dormir e o levantar. Na brincadeira, a criança dá outros sentidos aos objetos e jogos, seja a partir de sua própria ação ou imaginação, seja na trama de relações que estabelece com os amigos com os quais produz novos sentidos e os compartilha.

Contudo nem sempre foi assim, as crianças até o século XVIII eram vistas como pequenos adultos e cada vez mais cedo eram iniciadas ao trabalho e rotina dos adultos de sua família e comunidade. Jogos e brincadeiras foram retratados com pouca frequência na época; conclusão esta tirada do fato de que a historiografia sobre o tema já está bastante avançada. 
Àries (1986), construindo uma historiografia sobre jogos e brinquedos fala sobre o cotidiano da vida de um pequeno Delfin, que mais tarde seria Luís XIII, rei da França, através dos escritos do diário do médico da família real Dr. Heroard.

Heroard registra que o menino, com um ano e cinco meses toca violino e canto ao seu tempo. "Antes ele se contentava com brinquedos habituais dos pequeninos, como o cavalo de pau, o catavento e o pião" (ÀRIES, 1986, p. 83). A infância era vivida em um mundo adulto e aos sete anos o pequeno Delfin deixa de ser visto como uma criança para ser tratado como um pequeno adulto sob a tutela de um protetor (educador) que "tenta fazê-lo abandonar os brinquedos da primeira infância, essencialmente as brincadeiras de bonecas: 'não deveis mais brincar com esses brinquedinhos (brinquedos alemães), nem brincar de carreteiro: agora sois menino grande, não sois mais criança" (ÀRIES, 1986, p. 87).

Para Àries (1986) tudo indicava que a idade de sete anos marcava uma etapa de certa relevância: era a idade geralmente fixada pela literatura moralista e pedagógica do século XVII para a criança entrar na escola ou começar a trabalhar. Até hoje tal visão ainda é difundida, pois muitas famílias colocam seus filhos na escola somente aos sete anos, acreditando que é a partir dessa idade que se inicia o processo de maturação do seu desenvolvimento cognitivo e social.

É relevante afirmar que por volta de 1600, a especialização das brincadeiras atingia apenas a primeira infância; "depois dos três ou quatro anos, ela se atenuava e desaparecia. A partir dessa idade, a criança jogava os mesmos jogos e participava das mesmas brincadeiras dos adultos, que entre crianças, quer misturada entre os adultos" (ÀRIES, 1986, p. 92).

É a partir do século XV que os artistas começaram a representar com mais frequência a vida cotidiana das crianças, principalmente suas brincadeiras. Nessas pinturas reconhecem o cavalo de pau, o cata-vento, o pássaro preso por um cordão e em poucas obras eram retratadas as bonecas.

Àries (1986) afirma que várias brincadeiras têm origens mais remotas. Um exemplo disso é o pássaro de madeira amarrado em uma correntinha que a criança segura. Tal brinquedo era o mesmo na Grécia Antiga, contudo o brinquedo não era um elemento individual e sim uma liturgia coletiva. Com o passar do tempo perdeu-se o seu caráter 
cerimonial, pois existia uma relação estreita entre a cerimônia religiosa comunitária e a brincadeira que compunha o seu rito, passando a se um simples brinquedo individual.

O autor nos traz uma interessante reflexão a esse respeito ao se questionar se esses brinquedos sempre pertenceram ao mundo das crianças ou se antes pertencia ao mundo dos adultos, visto que tais brinquedos buscam retratar a vida adulta: o cavalo de pau: o meio de transporte mais usado, o cata-vento: os moinhos de vento e as bonecas a própria imitação da função da mulher: criar seus filhos. Tais brinquedos deixam clara a hipótese do autor de que as brincadeiras da criança é uma imitação do mundo adulto em uma pequena escala.

Contudo, isso não só se restringia às crianças. Àries (1986) comenta que inversamente os adultos participavam de jogos e brincadeiras que hoje são reservadas às crianças. Uma análise historiográfica de produções artísticas em calendários da época permitia-se observar gravuras retratando jogos como o "pega-parceiro", guerrinhas de bola de neve, cabra-cega e até mesmo esconde - esconde. Citando Vam Marle, o autor expõe : "quanto aos divertimentos dos adultos, não se pode dizer realmente que fossem menos infantis do que as diversões das crianças" (ÀRIES, 1986, p. 92).

Interessante é observar que os brinquedos e jogos são o instrumento de construção do entendimento do real vivido pelas crianças. Todos esses brinquedos ainda são vendidos e nos leva a afirmar que "as crianças constituem as sociedades humanas mais conservadoras" (ÀRIES, 1986, p. 89). O tempo não descaracteriza o real valor e os significados que a brincadeira, o brinquedo o jogo tem e representam para a criança e dessa forma nunca perderá seu sentido.

Segundo Piaget os jogos infantis constituem admiráveis instituições sociais. Para ele os jogos de bolinha de gude (jogos de bolinha) comportam um sistema complexo de regras. "Como em todas as realidades ditas morais, as regras do jogo de bolinhas se transmitem de gerações a gerações e se mantém unicamente graças ao respeito que os indivíduos tem por elas". (PIAGET, 1977, p.21)

Utilizando-se de estudos sobre o jogo, sonhos e imitação nas crianças, desenvolvido por Jean Piaget, (ROSAMILHA, 1979), cita três classificações para jogos e brinquedos construídos por Piaget: 
- Jogos práticos : brinquedo funcional, que são explorações sensoriais motoras

- Jogos simbólicos: dramatização e substituições de ações, gradativamente incorpora-se a imitação e passando a ser brinquedos sócio - dramáticos.

- Jogo com regras: seguir regras ou compreendê-las.

Em termos de aprendizagem motora a dedução de que quanto mais rica for a vivência em atividades que trabalham o corpo e o movimento maior será o desenvolvimento, isso se dá pela ideia de que as experiências perceptivo motoras baseiam-se no estímulo sensorial enviado ao cérebro do indivíduo onde por meio deste o indivíduo utiliza-se de experiências passadas para perceber a uma nova resposta indicada (FLINCHUM, 1986).

"O movimento humano não pode ser limita a um conjunto de articulações e de forças. Ele precisa ser compreendido no contexto de todas as dimensões humanas. Antes de ser um fenômeno físico, o movimento é um comportamento, uma postura, uma presença, uma intencionalidade. Assim, o movimento não é só uma linguagem, mas torna-se uma fonte inesgotável de simbologia que lhe confere uma grandeza ilimitada". (SANTIN,1987, p. 63)

Nas várias possibilidades que o brincar oferece, "É no brinquedo que a criança aprende a agir numa esfera cognitiva, ao invés de numa esfera visual externa, dependendo das motivações e tendências íntimas, e não dos incentivos fornecidos pelos objetos externos". (VYGOTSKI, 1998, p.126)

Chateu (1987) ressalta que desde muito cedo o jogo na vida da criança é de fundamental importância, pois quando ela brinca, explora e manuseia tudo aquilo que está a sua volta, através de esforços físicos, mentais e sem se sentir coagida pelo adulto, começa a ter sentimento de liberdade e satisfação pelo que faz, dando, portanto, real valor e atenção às atividades vivenciadas naquele instante.

É sabido que a criança pequena tem necessidade de que suas vontades sejam realizadas imediatamente. Quando a criança começa a compreender que suas vontades não são de pronto atendidas, ela cria uma situação imaginária, de faz-de-conta, em que é possível atingir aquilo que concretamente não lhe é permitida. Embora imaginária, a situação é similar à realidade não atendida. Este movimento implica determinadas 
regras de comportamento. "É no brinquedo que a criança aprende a agir numa esfera cognitiva". (VYGOTSKY, 1998, p. 113)

Dessa forma o papel da escola pode ser entendido como o de valorizar os conhecimentos que as crianças possuem e garantir a aquisição de novos conhecimentos. Assim, o "brincar permite à criança um melhor domínio sobre a comunicação, a faz entrar em um mundo de comunicações complexas, que depois vão ser utilizadas na educação, nas simulações educativas, nos exercícios educativos" (BROUGÈRE, 1998, p. 4)

Com o surgimento dos brinquedos eletrônicos fez com que o lúdico se tornasse uma atividade pacífica e limitada. Mas é a criança que deve ser criativa na realização de uma atividade na qual ela mesma se interesse e se liberta se sentido a vontade, lhe proporcionando prazer e sem ela mesma saber lhe proporcionando grandes benefícios. "O jogo, atendendo a uma das necessidades mais profundas, da criança, é por excelência, o meio de captar lhe o interesse". (CLAPARÈDE, 1858, apud BELTRAMI, 1997)

Para Vygotski (1998) a essência do brinquedo é a criação de novas relações entre as situações no pensamento e situações reais. "Em um sentido, no brinquedo a criança é livre para determinar suas próprias ações. No entanto, em outro sentido, é uma liberdade ilusória, pois suas ações são, de fato, subordinadas aos significados dos objetos e a criança age de acordo com eles". (VYGOTSKI, 1998, p.136)

Vygotski acredita que a imaginação, assim como todas as funções da consciência surgem da ação, "a imaginação, nos adolescentes e nas crianças em idade pré - escolar é o brinquedo sem ação" (VYGOTSKI, 1998, p. 123), ou seja, no brinquedo, no jogo ela cria uma situação imaginária.

O jogo pode e deve vir a colaborar com o desenvolvimento da criança proporcionando momentos de prazer e satisfação em participar, pois:

"o jogo ou o brinquedo, como atividade agradável, não pode ser confundido com o jogo no sentido de "partidas", "competições", que podem significar obrigação, treinamentos, atividade difícil, fanatismo, ansiedade (...) Toda vez que o elemento competitivo ou agressivo suplanta os demais atributos do jogo, brinquedo. O jogo - brinquedo é 
em essência, de natureza criativa (...) por isso alguém já afirmou que a arte é brinquedo concentrado". (ROSAMILHA, 1979, p.94)

O jogo deve vir com todas as suas características, não devendo subestimar as regras e sim fazer com que elas venham a contribuir com o objetivo do professor. Piaget (1975) afirma que a atitude da criança em utilizar-se do jogo com regras bem como utilizar-se de dados da realidade adaptando-a a fantasia, ou seja, jogando, mas imitando o real é senão consequência da socialização da criança.

Quando a criança brinca explora o seu próprio corpo, suas emoções e experiências, ela vivência e aprende os domínios do comportamento humano tais como criatividade, responsabilidade, consciência corporal, noções espaço - temporal, percepções visuais, auditivas, lateralidade, ritmo, capacidade de atenção e concentração.

\subsection{O lúdico e sua relação com a aprendizagem}

A brincadeira das crianças é uma estrutura ligada às características da infância. A criança é um ser em constante desenvolvimento e é através da brincadeira, do lúdico que a criança desenvolve para o seu prazer e sua recreação essa atividade, que permite a ela entrar em contato com os adultos, os pais, as crianças de sua idade e também com o espaço, com o meio ambiente, com a cultura na qual vive. $\mathrm{O}$ que talvez caracterize a brincadeira é o fato de permitir à criança um espaço, uma possibilidade de ação que a criança domine ou, pelo menos, exerça em função de sua própria iniciativa e permitir a ela uma relação com a aprendizagem.

Vygotski (1998) não vê uma grande relevância na limitação de divisão de níveis ou estágios de desenvolvimento. O importante é perceber as relações que realmente acontecem entre o processo de desenvolvimento e a capacidade de aprender da criança. Para isso determinou dois níveis de desenvolvimento: nível de desenvolvimento real (nível de desenvolvimento das funções mentais das crianças onde se leva em conta a autonomia delas, aquilo que elas conseguem fazer por si mesma) e o nível de desenvolvimento potencial (que é determinado através da capacidade da criança de solucionar problemas utilizando-se da orientação de um adulto ou em colaboração com companheiros. 
Vygotski cria um novo conceito, Zona de Desenvolvimento Proximal, que define uma fase intermediária entre o nível de desenvolvimento real e o nível de desenvolvimento potencial, ou seja, permite perceber que funções ainda não chegaram a maturação, mas que estão em processo.

\footnotetext{
"A Zona de Desenvolvimento Proximal permite-nos delinear o futuro imediato da criança e seu estado dinâmico de desenvolvimento, propiciando o acesso não somente ao que já foi atingido através do desenvolvimento como também àquilo que está em processo de maturação (...) a zona de desenvolvimento proximal hoje, será o nível de desenvolvimento real amanhã, ou seja, aquilo que uma criança pode fazer com assistência hoje, ela será capaz de fazer sozinha amanhã". (VYGOTSKI, 1998, p. 113)
}

Almeida (1995) diz que a brincadeira simboliza a relação pensamento - ação da criança, e, sendo assim, constitui-se provavelmente na matriz de formas de expressão da linguagem (gestual, falada ou escrita) (A guiar, 2005).

Essa relação entre a aprendizagem e a brincadeira é o fato de que a criança aprende a brincar; e ao aprender a brincar, ela aprende certo tipo de comunicação que a permita estabelecer formas de comunicação da vida comum; contudo o que se vai fazer não é a mesma coisa que se faz na vida comum, pois se utiliza da fantasia e imaginação ao usar uma pedra como um pedaço de pão, uma boneca como um bebê de verdade. Assim, ao mesmo tempo em que, "Brincar permite à criança um melhor domínio sobre a comunicação, a faz entrar em um mundo de comunicações complexas, que depois vão ser utilizadas na educação, nas simulações educativas, nos exercícios educativos" (BROUGÈRE, 1998, p. 4).

A brincadeira pode ser entendida como algo complexo porque é precedida por algumas fases de exploração, que ainda não são verdadeiramente fases do jogo na qual a criança descobre e aprende a manipular.

Podemos dizer que o jogo não tem consequências, ou seja, quando a brincadeira termina o mundo não vai ser transformado e sempre se pode recomeçar o jogo. Essa ausência de consequências faz com que o jogo seja um espaço sem riscos, onde se pode experimentar, inventar, tentar alguma coisa sem o risco de ser repreendido pelo real. 
Partindo desse princípio podemos pensar em utilizar o jogo como um tipo de laboratório da infância a fim de tentar construir um espaço entre o jogo e as atividades dirigidas, mediadas pelos conhecimentos específicos oferecidos pelos professores. Contudo devemos ter clara a ideia de que intervir em uma brincadeira e/ou jogo é nunca ter certeza do que vai acontecer, e sim aumentar a probabilidade da atividade, caminhar rumo ao que interessa ao educador. Isto vai se dar através do ordenamento do espaço, ao organizá-lo em função dos objetos à disposição: brinquedos, elementos complementares aos brinquedos, ou elementos do imobiliário.

A aprendizagem vem acompanhada do prazer quando as atividades lúdicas são reconhecidas como meio de fornecer um ambiente agradável, motivador, planejado e enriquecido, que possibilita a aprendizagem de várias habilidades (AGUIAR, 2005).

É nessa relação entre a aprendizagem e a brincadeira que a criança estabelece formas de comunicação da vida comum através da fantasia e imaginação como, por exemplo, quando ela utiliza uma pedra como um pedaço de pão ou uma boneca como um bebê. De acordo com experimentos em relação à ação e significado no brinquedo, Vygotsky (2007), percebeu que quando a criança brinca, ela lida com o significado dos objetos e não com o objeto em si. Ao lidar diretamente com os significados a criança sai do mundo perceptório imediato e entra no mundo simbólico.

Segundo Vygotsky (2007), o desenvolvimento e o processo de aprendizagem têm no brinquedo um essencial aliado. As brincadeiras de faz-de-conta, que são atividades tipicamente infantis fornecem um lugar de desenvolvimento que possibilita novas formas de desejo imprescindíveis para o desenvolvimento da ação real e da moralidade.

Piaget (1962: 1976, apud AGUIAR, 2005, p. 26) diz que "a atividade lúdica é o berço obrigatório das atividades intelectuais da criança, sendo, por isso, indispensável à prática educativa".

Nos dois contextos - o brinquedo e a instrução escolar:

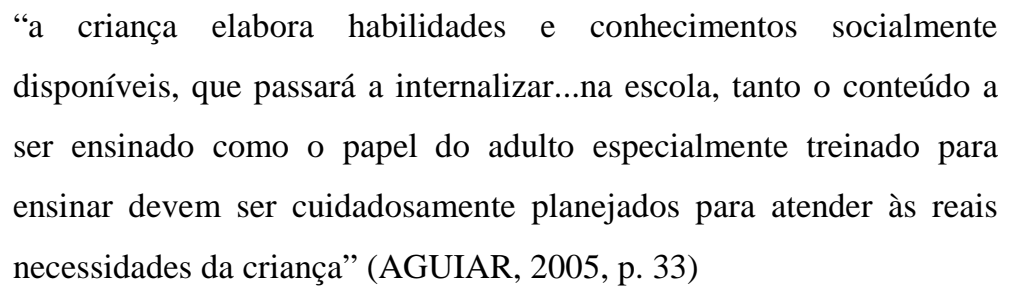


Para Brougère (1998) a chave de todas essas intervenções é o da observação, porque é preciso respeitá-la bastante para poder intervir, conhecer bem o jogo da criança, sua cultura, como se brinca, de que maneira, do quê, e ver quando o jogo pode ser desenvolver dentro de sua própria lógica, quando é interessante nele intervir. 


\section{OBJETIVOS}

\subsection{Objetivo Geral}

Compreender, a partir da percepção de professores que atuam na sala de recurso, como ocorre o uso pedagógico das atividades lúdicas para o processo de inclusão da criança especial na Educação infantil.

\subsection{Objetivos Específicos}

Analisar as contribuições das brincadeiras e atividades lúdicas para o desenvolvimento da criança especial nos seus aspectos psíquicos, social, afetivo e motor.

$>$ Analisar a importância das atividades lúdicas no processo de ensino-aprendizagem da criança especial.

Identificar como o professor, em sua prática pedagógica, utiliza o lúdico de modo que favoreça a inclusão da criança especial. 


\section{METODOLOGIA}

\subsection{Fundamentação Metodológica}

Este trabalho segue as orientações da pesquisa qualitativa, que visa compreender o fenômeno estudado como um processo cíclico, em que a construção de uma dada realidade e a compreensão do objeto de estudo realizam-se entre pesquisador e pesquisado. De acordo com Godoy (1995), são características de uma pesquisa qualitativa: o lugar dos participantes é o foco de todo o processo da pesquisa, os quais são entendidos como aqueles que têm uma história particular e coletiva que deve ser considerada; a participação do pesquisador como elemento chave, pois à medida que analisa o fenômeno, ele imprime suas crenças e visões de mundo; o que confere a pesquisa qualitativa um caráter interpretativo; no qual o processo é mais importante que o produto.

A pesquisa qualitativa ainda não dá menção aos eventos estudados e não emprega instrumentos estatísticos na análise dos dados, ela envolve a obtenção de dados descritivos sobre as situações e as pessoas, visando compreendê-las em suas complexidades.

Gil (1991) afirma que, "embora as pesquisas geralmente apontem para objetivos específicos, estas podem ser classificadas em três grupos: estudos exploratórios, descritivos e explicativos" (GIL, 1991, p. 46). Esta pesquisa tem a especificidade de ser exploratória por envolver pesquisa bibliográfica, entrevistas com indivíduos que possuem experiência ou alguma relação com o tema e que, portanto, ajuda a coconstruir a compreensão sobre o fenômeno em estudo.

Para apreender a complexidade do fenômeno, a pesquisa qualitativa utiliza instrumentos que possibilitam aos participantes expressarem-se espontaneamente. É o caso da entrevista semiestruturada que busca valorizar o entrevistado, sua história, suas percepções e significados sobre o mundo. Por meio de perguntas abertas e sem imposições do pesquisador, a entrevista semiestruturada coloca-se mais como um empreendimento social e cooperativo, em que a interação entre pesquisador e entrevistado promove a negociação de significados e trocas de ideias na perspectiva de explorar e conhecer o fenômeno estudado (BAUER e GASKELL, 2000). 
Segundo Triviños (1995) ao usar um roteiro aberto de perguntas, existe a possibilidade de um campo interrogativo mais amplo e que toma contornos próprios à medida que a interação entre esses interlocutores se desenvolve.

\subsection{Contexto de pesquisa}

A pesquisa foi realizada em uma escola pública inclusiva localizada em uma cidade satélite de Brasília. Essa escola atende alunos da Educação Infantil do primeiro ao quinto ano, alunos com NEE incluídos em sala com número reduzido de crianças e também atende turmas especiais. Nela há o atendimento educacional especializado que acontece nas salas de recurso com intuito de atender alunos com NEE. Esse atendimento se destina aos alunos incluídos que após passarem por avaliação pedagógica são encaminhados para esse atendimento, que acontece duas vezes por semana, com duração de uma hora cada. O total de crianças com NEE chega ao número de setenta alunos e os que são atendidos na sala de recurso chega a vinte e três alunos.

\subsection{Participantes}

Os participantes da pesquisa foram dois professores de sala de recurso que trabalham com alunos incluídos. Por questões éticas, o nome os professores entrevistados não serão revelados, sendo aqui identificados como professor A e professor B. O primeiro é formado em magistério e com graduação em Matemática, tem trinta e três anos de idade e trabalha a quatorze anos como professor, dos quais nove são com alunos NEE. O professor $\mathrm{B}$, de quarenta anos de idade, tem formação em Pedagogia e trabalha a vinte anos como professor, sendo um ano dedicado aos alunos com NEE.

\subsection{Materiais e Instrumentos utilizados}

Foram utilizados como material uma câmera fotográfica com função de gravador, com o objetivo apenas de captar o áudio das entrevistas, papel e caneta. Como instrumento foi utilizado um questionário, cujo propósito foi de apenas conhecer as características pessoais e profissionais dos participantes nos seguintes aspectos: idade, formação, tempo de docência e tempo de atuação junto aos alunos com NEE. Como 
fonte maior de informação de pesquisa, foi utilizada entrevista semiestruturada, cujo roteiro continha perguntas abertas que giravam em torno de como ocorre o uso pedagógico do lúdico no processo de inclusão escolar da criança especial, que é atendida na sala de recurso (ver apêndice $\mathrm{A}$ ).

\subsection{Procedimentos de Construção dos dados}

Inicialmente foi feito o contato com a escola através de seu diretor, em que na ocasião foi entregue a ele a carta de apresentação da pesquisa (ver anexo A), na qual continha os objetivos e o cuidado com as questões éticas por parte da pesquisadora. Após aprovação do diretor, o próximo passo foi angariar participações dos professores que trabalham na sala de recurso. A eles foi entregue o Termo de Consentimento Livre e Esclarecido (ver anexo B). Após assinatura do termo, foram agendados os horários para as entrevistas com os professores no turno da sua coordenação pedagógica sendo este o momento em que se dispuseram.

Todas as entrevistas ocorreram no espaço escolar do professor, foram individuais, gravadas na íntegra e transcritas para posterior análise.

\subsection{Procedimento de análise dos dados}

As entrevistas foram lidas e relidas, buscando, em um primeiro momento, apreender os significados que os professores construíram sobre o tema tratado. Uma segunda leitura foi realizada com o objetivo de associar a literatura e as fala dos participantes. A partir de uma terceira leitura, as categorias de análise foram construídas tendo por referência as falas dos entrevistados: 1 - percepção dos professores sobre a inclusão e o aluno especial; 2 - o uso do lúdico como estratégia pedagógica; 3 - o desenvolvimento do aluno com NEE a partir das atividades lúdicas. 


\section{RESULTADOS E DISCUSSÕES}

O objetivo deste capítulo é apresentar as categorias de análise que emergiram a partir das falas dos participantes. Foram retirados os trechos mais significativos que revelam os significados construídos pelos professores sobre o tema em questão.

\subsection{Categoria 1 - Percepção dos professores sobre a inclusão e o aluno especial}

Na primeira categoria pretendemos destacar a percepção do professor que atua na sala de recurso, que trabalha diretamente com crianças especiais, sobre o processo de inclusão e os significados que eles constroem sobre seus alunos com NEE incluídos.

Segundo o professor A, o processo de inclusão é um movimento necessário que ainda precisa de muita coisa para que de fato aconteça. Conforme suas palavras:

\footnotetext{
A inclusão é algo maravilhoso e inevitável porque a sociedade é feita por essas diferenças, e a inclusão visa justamente atender essa diversidade, essas diferenças. Agora o processo ainda é em pequenos passos é uma coisa que tem acontecido de forma muito lenta, mas entendo que ainda sim estamos evoluindo (professor A).
}

O fato de que "estamos evoluindo" reflete uma percepção do professor de como o processo de inclusão tem acontecido e a vontade de que realmente aconteça uma inclusão que atenda a todos dentro de suas necessidades respeitando as diferenças.

O professor B, por sua vez, afirma que para a efetivação do processo de inclusão, a prática e as relações cotidianas da escola, tornam-se essenciais:

A inclusão parte da exclusão porque a exclusão se dá na prática no dia a dia, e para fazer a inclusão a gente também tem que partir da prática do dia a dia, principalmente na garantia dos direitos básicos da pessoa de forma igualitária. Uma pessoa que é vítima da exclusão ela vem de uma exclusão diária, continua até chegar em um momento em que ela está completamente fora da sociedade, seja pelo motivo da questão racial, seja por uma questão da deficiência física e algumas outras que podemos citar. A inclusão tem que ser concebida a partir da prática, não dá para fazer inclusão de forma teórica (professor B). 
Garantir os direitos é uma forma de incluir, e todo ser social tem necessidade de que essa garantia seja cumprida e essa é uma maneira de fazer com que a inclusão aconteça e a escola é um lugar em que essa prática venha ser sempre presente.

O trabalho dos professores entrevistados acontece na sala de recurso, e foi questionado como esse espaço tem atendido a criança especial. Os professores explicaram que é um atendimento complementar que acontece no contra-turno da aula da criança, duas vezes por semana e com duração de uma hora. Esse atendimento pode ser feito de forma individual ou em grupo conforme a necessidade da criança. O professor A ressaltou que "nós não estamos na sala de recurso para trabalhar exclusivamente conteúdo como uma aula de reforço". É importante perceber que o trabalho na sala de recurso tem objetivos que vão além de apenas ensinar conteúdos, ele atende a criança naquilo que ela necessita, seja na parte cognitiva, afetiva e social e o fato de acontecer de duas formas, individual e em grupo, permite um melhor desenvolvimento e alcance dos objetivos.

Sendo um trabalho tão direcionado, a prática pedagógica desse professor deve vir a contribuir com a inclusão. Como isso acontece foi questionado aos professores. $\mathrm{O}$ professor A respondeu que sua prática pedagógica acontece de modo que "atenda a necessidade da pessoa como um todo...trabalhamos a questão afetiva, motora, autoestima, sentimentos, como ela vai se expressar para que ela se torne mais resiliente". O professor exprime o desejo de trabalhar o ser como um todo e fazer com que seu aluno se sinta mais capaz de ir além de sua deficiência e se posicionar positivamente frente às adversidades, sendo motivado a agir de forma positiva às reações adversas que irá enfrentar. O professor ainda diz que:

\footnotetext{
Não esquece a questão do conteúdo, algo que pode fazer com que a criança se sinta um pouco mais igual, menos deficiente em sala de aula, então quando a gente faz esse trabalho, certamente o reflexo imediato na sala de aula porque as crianças passam a acompanhar mais, a se aceitar mais, aceitar o grupo (professor A).
}

A contribuição do professor B mostra seu envolvimento nos planejamentos das atividades previstas na escola, com intuito de garantir a participação dos seus alunos nessas atividades e também um envolvimento com todo o corpo escolar para garantia dos direitos dessa criança, assim ele diz: 
A gente participa dos projetos, na elaboração desses projetos e na execução dos mesmos, porque às vezes quem está elaborando não tem em vista essas crianças, elaboram algo para todos, e acabam excluindo as crianças que não está prevista ali dentro uma estratégia que promovam a inclusão dessas crianças, nós participamos do conselho de classe, nós participamos de qualquer atividade da escola que tenha, seja pedagógico ou não, nós estamos lá para garantir a participação dessas crianças especiais. Fazemos também oficinas com os pais, com os professores e funcionários da escola...então todos conhecem nossos alunos especiais e todos sabem lidar com eles (professor B).

A relação que pode ser estabelecida entre o aspecto pedagógico das atividades lúdicas e o processo de inclusão foi respondida pelos professores de forma muito direta e clara, não fazendo distinção do brincar para qualquer que seja a criança, como respondeu o professor A: "Brincar é para todos. Independente de você falar, andar, correr o lúdico agrega as pessoas elas se tornam mais iguais”. A frase relata que essa relação é importante para criança especial, pois, conforme o professor B:

Brincando a criança acaba exercitando essas vivências de regras sociais, limites e também participam de atividades cooperativas. Esse é um exercício que ela faz aqui na sala de recurso, que ela acaba transferindo esse exercício para outros grupos sociais de que ela convive lá fora (professor B).

Desta forma, percepções e práticas mais conscientes sobre uma escola inclusiva colaboram para efetivação da inclusão e para uma educação de qualidade a todos os alunos, indiscriminadamente (AGUIAR, 2005).

\subsection{Categoria 2 - o uso do lúdico como estratégia pedagógica}

Já na segunda categoria percebemos que o professor de sala de recurso dentro do seu planejamento, usa como estratégia pedagógica o lúdico nas suas formas variadas para alcançar os objetivos que foram planejados por ele.

Essa afirmação foi confirmada pelos professores quando falaram que o lúdico é a base de sua estratégia e que utiliza o jogo como recurso principal estando dentro do seu planejamento. O professor B ainda afirma que o jogo "motiva a aprendizagem da criança” e que através dele o professor "começa a desenvolver as habilidades".

No currículo da Educação Infantil o jogo é um dos componentes fundamentais, garantida como um direito. Ele é um aliado do professor no direcionamento da sua aula na busca de resultados dentro daquilo que ele deseja alcançar visando o 
desenvolvimento, aprimoramento e a conquista de novas habilidades atendendo a necessidade e o progresso de cada criança. Froebel (1826, apud AGUIAR 2004) afirma que as crianças aprendem por meio do brincar, e este é um admirável instrumento para promover sua educação. É necessário que o professor compreenda e aproveite esse momento lúdico para que sua aula venha de fato contribuir no processo educativo e desenvolvimento da criança especial.

Ao se tratar o lúdico no processo ensino-aprendizagem os professores reafirmaram que "o lúdico é a chave da aprendizagem”, porque segundo o professor A, "quando brincamos, jogamos, nós estamos a todo momento expondo o mecanismo de pensamento, de conhecimento...de forma muito espontânea" e que nesse momento é feito algumas intervenções que são pontuadas para depois sistematizar os pontos que deseja. O professor B afirma que há "a aquisição das habilidades sem esforço, ela vai brincando, vai participando e a gente vai fazendo as intervenções”. Esse momento, realizado na sala de recurso, os professores conseguem direcionar, sendo diferente do trabalho feito na sala de aula que é mais "acadêmico, sistemático".

Vygotsky (1998), expressa com clareza a importância do jogo enquanto instrumento que favoreça o desenvolvimento da criança. Para esse autor, a brincadeira, quando proposta pelo professor, deve ser combinada de alguma maneira com o nível de desenvolvimento da criança, a fim de promover ganhos pedagógicos mais significativos.

Essa é a idéia da aprendizagem prazerosa, que através de jogos a criança se permite explorar e vivenciar de forma espontânea o que aquela atividade oferece conquistando novos conhecimentos e habilidades, tendo o professor a oportunidade de observar e intervir naquele momento. Essa ação auxilia os professores a conhecerem melhor os alunos com os quais trabalham e permite que ele adapte a atividade conforme a necessidade da criança especial.

Alves (2002, apud AGUIAR 2005), ao analisar o jogo no processo de aprendizagem, diz que a inteligência gosta de brincar e que é brincando que se aprende. Para ele, a brincadeira é tônico para a inteligência. Todavia, a aprendizagem não se limita apenas ao aspecto intelectual ela vai muito além disso. Ela envolve dimensões como a motora e cognitiva, as quais andam juntas, bem como a importância da afetividade que tem reflexo direto no que aprendemos e pensamos, como também na questão social que tanta diferença faz no trabalho com crianças especiais. 
Os professores entrevistados relataram que quando utilizam o lúdico na sala de recurso, percebem grandes ganhos nos aspectos, cognitivo, afetivo, social e motor no trabalho com essas crianças e que esses ganhos podem também ser generalizados para os outros contextos. No aspecto cognitivo, o professor B "percebe o desenvolvimento da atenção, desenvolvimento da concentração da criança e da memória". O professor A exemplifica um trabalho mais pontual quando utiliza o jogo de português, percebendo que este "reflete diretamente como ele vai escrever, como ele vai ler".

Piaget (1962; 1976, apud AGUIAR, 2005) diz que a atividade lúdica é indispensável à prática educativa pelo fato de o jogo ser um meio tão poderoso para a aprendizagem das crianças, em todo lugar onde se consegue transformar em jogo a iniciação à leitura, ao cálculo ou à ortografia.

$\mathrm{Na}$ questão afetiva o professor A relatou que "percebe as crianças muito mais seguras, mais felizes quando elas estão brincando". O professor B relata o trabalho que foram realizados com as crianças nas oficinas de beleza, por exemplo, com intuito de se trabalhar a auto-estima. Nesse sentindo, Marcellino (1988, apud AGUIAR 2005) faz referência a importância do lúdico pelo prazer e felicidade que ele proporciona, sendo que nenhuma outra razão precisa ser acrescentada para afirmar a sua necessidade. $\mathrm{O}$ sentir-se bem leva a um bem-estar consigo e com o outro.

O professor B citou que seus alunos com deficiência intelectual, que "apresentam um atraso na fala, timidez”, melhoram consideravelmente o aspecto da comunicação (gestual, oral, escrita) quando se utiliza o lúdico enquanto recurso pedagógico.

O trabalho pedagógico do professor é de fazer com que proponha situações que exijam respostas de movimento que os faça interagir com o meio e com os outros. Freire (1995) remete a ideia de que a educação motora significa educar as habilidades motoras que permitem o sentir e o expressar do homem, ou seja, expressar sentimentos, pensamentos por meio de habilidades motoras educáveis, habilidades estas em um processo de desenvolvimento e aprendizagem.

Interessante foi perceber a preocupação dos professores em relação aos seus alunos em dois aspectos distintos da educação motora. O professor A "pensa muito na coordenação motora fina...no pegar no lápis, no fazer”, citando ganhos nesse aspecto quando se trabalha atividades voltadas para esse objetivo. Já o professor B preocupou-se com "uma melhora na consciência corporal, nos esquemas corporais, nas finalidades", 
utilizando a música e a dança para alcançar esses objetivos e no autoconhecimento da criança.

Segundo Le Boulch (1983, p. 3), o esquema corporal se define como "uma intuição de conjunto ou conhecimento imediato que temos de nosso corpo em posição estática ou em movimento" e através da música e de movimentos livres a criança percebe seu corpo, sua posição no espaço e cria conforme suas experiências corporais, ideias e sentimentos.

Para Flinchum (1986), há provas evidentes de que o sucesso em habilidades físicas contribui para a melhora do auto-conceito e para o reforço positivo de sua auto-imagem. Os jogos ainda colaboram no sentido de que permite a liberdade de ação, pulsão interior, naturalidade, atitude e, consequentemente prazer, raramente encontrados em outras atividades escolares.

Atividades lúdicas que proporcionam essas sensações são inúmeras, mas o objetivo deve ser voltado para a busca de resultados e benefícios que elas proporcionam de modo que venham colaborar com o desenvolvimento da criança. Foi pedido aos professores que dessem exemplos desse fato. Ao citá-los foi percebido a preocupação desse professor que trabalha na sala de recurso em desenvolver um trabalho que venha acrescentar e colaborar com o professor da sala tendo o aluno um ganho em sua aprendizagem. O professor A citou exemplos de jogos muito utilizados como o jogo da memória pela possibildade que ele tem de poder aumentar o número de fases, aumentando assim a dificuldade e fazer com que ela se sinta segura e que goste de trabalhar, pois "a atenção a memória rapidamente a gente consegue perceber na sala de aula; a concentração, o saber, como é a sequência que o professor passa”.

O quebra cabeça é visto como um jogo que ajuda no trabalho com aquelas crianças que apresentam dificuldade na discriminação visual que acaba atrapalhando sua alfabetização, na identificação das letras por exemplo, pois "as vezes é como ela vê aquela letra, como ela vê aquilo que está sendo escrito, grafado", ela não consegue fazer a assimilação necessária para o aprendizado da leitura.

O professor B cita os jogos em geral que ajuda na elaboração de alguns conceitos e estratégias e de como que eles permitem uma:

Melhora muito grande na abstração das crianças principalmente em relação aos conceitos matemáticos que é onde as crianças especiais principalmente as crianças com deficiência intelectual que tem mais dificuldade (professor B). 
Para a professora, há um ganho significativo na concentração e na memória com o trabalho desse jogo, complementando que os tipos de jogos de mesa, de raciocínio e de estratégia, nunca perderão seu valor por permitir um estímulo no desenvolvimento cognitivo. De acordo com Bomtempo (1997, apud CORDAZZO, VIEIRA 2007) quando o déficit no desenvolvimento é detectado, ele pode ser estimulado e sanado, por meio das atividades lúdicas, permitindo a criança um maior preparo para determinados tipos de aprendizagem que anteriormente poderia apresentar dificuldades.

Dentro desse mesmo aspecto entra a oralidade, que é trabalhada por ambos os professores. Segundo eles, através de peças teatrais, por exemplo, pode-se perceber que as crianças ficam mais livres, elas criam e falam mais. À medida que desenvolvem essas habilidades, elas se expressam notavelmente em sala de aula também. Esse tipo de trabalho aparece, segundo o professor B, sobretudo, naquelas peças teatrais em que trabalha com algum livro, a escrita, o reconto da estória e a possibilidade da criação livre da criança, na qual ela pode (re)criar, (re)interpretar e mudar o final da estória.

A música também é citada como um recurso lúdico utilizado pelo professor B com crianças especiais. Segundo ele, a música favorece "principalmente a expressão oral, a criança falar, a criança cantar, as palavras que são ditas, a escrita a partir da música, a memória a partir da música também e a expressão corporal, a música que mexe com o corpo inteiro".

Esses dois tipos de recurso citados pelos professores são estratégias muito pouco utilizadas nas escolas. O contrário deveria ser verdade, pois tais recursos buscam abordar não só o aspecto motor, mas principalmente o afetivo, podendo ser trabalhado a questão da comunicação, a inibição e amizade, bem como a questão social (interação entre os alunos).

Vygotski (1998) questiona o fato de muitos teóricos trabalharem a questão do desenvolvimento da criança apenas do ponto de vista intelectual. Assim, ele ressalta a importância de se observar os incentivos que permitam colocá-la em ação, em movimento. 


\subsection{Categoria 3 - o desenvolvimento do aluno com NEE a partir das atividades lúdicas}

Na terceira e última categoria, destacamos as variadas formas de utilização do lúdico nas atividades realizadas na sala de recurso com crianças especiais, e como este contribui para o seu desenvolvimento.

Nas atividades lúdicas realizadas de forma livre, individual e em grupo, alguns comportamentos são muito perceptíveis, e se tornam muito importante no trabalho com crianças especiais na busca de desenvolver um trabalho voltado para necessidade específica de cada criança, sendo assim foi questionado aos professores quais são essas percepções.

Os professores relataram que nas atividades livres percebe-se a espontaneidade das crianças, elas tem a oportunidade de criar, elas se sentem livres de qualquer regra e acabam fazendo suas escolhas. Dessa forma ela fantasia, constrói uma ponte entre o mundo inconsciente com a realidade que a rodeia. Conforme Rosamilha (1979, p. 56), "no brinquedo ela fantasia e vive de forma vicária seus sonhos, no contexto de sua realidade...ela começa a sujeitar sua fantasia ao princípio da realidade, ao controle consciente. O jogo é usado para torná-la mestre de si própria”.

Nas atividades individuais "ficam mais perceptíveis as dificuldades das crianças e suas potencialidades que ela tem, porque você está com o foco só nela”. Essa é fala do professor A que se assemelha com a fala do professor B quando este diz que o ganho acontece pela oportunidade que ele tem de estar tão perto e poder "observar melhor as dificuldades das crianças".

Em grupo, comportamentos inesperados, atitudes e características tão pessoais podem ser observados. Segundo o professor A, “os líderes se apontam rápido no grupo, quem sabe competir, quem tem dificuldade para se expressar”. Já o professor B aponta, que além dessas questões, fatores como “a compreensão das regras, a comunicação oral e a cooperação dessa convivência de estar junto com o outro de estar ajudando”, a criança se sente importante pelo fato de pode ajudar o grupo apresentando o desejo de cooperar.

A brincadeira propicia momentos agradáveis de convivência social favorecendo o seu desenvolvimento biopsicossocial. Perceber o envolvimento com o jogo e com outro reflete: 
O aprendizado, desperta vários processos internos de desenvolvimento, que são capazes de operar somente quando a criança interage com pessoas em seu ambiente e quando em cooperação com seus companheiros. Uma vez internalizados, esses processos tornamse parte das aquisições do desenvolvimento independente da criança (...)" (VYGOTSKI, 1998, p.118).

O trabalho com atividades lúdicas realizadas em grupo com alunos incluídos permite alcançar alguns objetivos. O professor A listou alguns: ser cooperador, solidário, respeitar o outro, saber ouvir, se expressar, se colocar, o saber ganhar e perder quando se fala em competição. E no momento do jogo em grupo, este acaba se tornando importante para trabalhar outras questões como a fragilidade, a não aceitação do que é imposto e comportamentos de quem não sabe perder e ao trabalhar essas questões permite o amadurecimento e compreensão do convívio em grupo.

O professor B citou, como o primeiro objetivo do trabalho em grupo, a convivência social e igualdade de condições como o mais importante, por fazer parte da inclusão. Este aspecto é importante destacar pela preocupação que o professor demonstrou em incluir seus alunos sem discriminá-los proporcionando condições de igualdade. Nas atividades em grupo percebe-se o valor do trabalho de socialização, a forma com que as crianças se comportam e cooperam com a criança incluída refletem em muito o trabalho do professor com uma criança especial incluída. A criança especial e as outras crianças ganham ao perceberem que todos são diferentes. Também se preocupou na aprendizagem de se conviver com as diferenças citando um exemplo de uma criança com deficiência intelectual que discrimina uma criança com deficiência física, este fato muitas vezes é percebido, pois as crianças acabam interiorizando o preconceito que elas sofrem e acabam exteriorizando esse mesmo preconceito em outras crianças que possuem alguma deficiência.

Ambos os professores participantes citaram em seu discurso a compreensão das regras, Piaget (1975, p.182) afirma que "o jogo de regras é uma atividade lúdica do ser socializado". Isso se justifica pela aceitação de que as regras em um jogo vêm com intuito de definir uma ordem e sequência do que é proposto durante o jogo, de modo que não haja interferência que venha favorecer quem quer que seja quando estiver jogando. As regras também criam disciplina, respeito e sequência lógica da ordem do jogo. Mas essa aceitação não significa acomodação, a criança pode ser livre para 
modificá-las de acordo com seu contexto e de acordo com os objetivos do professor diante da atividade.

A participação do jogo não se prende apenas em jogar. O jogo pode ser modificado ou construído de forma que todos se beneficiem com o que ele pode oferecer. Essa participação pode ir além, as crianças podem propor atividades que mais gostam e essa é uma questão que foi perguntada aos professores, os quais afirmaram que esse fato acontece, pois em seu planejamento há um momento específico para que seus alunos tenham a liberdade de escolher e propor atividades e acabam optando por jogos com menos regras e com menor grau de dificuldade.

O professor B diz que, no planejamento na sala de recurso, sempre prevê atividades criativas, citando exemplo de uma atividade que ele realizou com seus alunos onde as crianças criaram uma estória coletiva baseada apenas nas imagens do livro que foi proposto. O professor ofereceu um livro aos alunos, eles folhearam, observaram as gravuras e a partir daí criaram uma estória com ilustrações criadas por eles e com esse material produziu um livro a partir das idéias do grupo. Depois eles tiveram acesso novamente ao livro utilizado como ponto de partida para criação, para conhecerem estória.

A infância e o movimento são entendidas como partes integrantes do desenvolvimento infantil, o professor deve ser o intermediador entre as atividades desenvolvidas com as necessidades de seus alunos, buscando alcançar resultados dentro de sua prática pedagógica que favoreçam a formação e o desenvolvimento global da criança através de atividades prazerosas. De acordo com Vygotski (1998, p. 113):

As crianças podem imitar uma variedade de ações que vão muito além dos limites de suas próprias capacidades. Numa atividade coletiva ou sob a orientação de adultos, usando a imitação, as crianças são capazes de fazer muito mais coisas.

Esse autor continua:

No brinquedo, a criança sempre se comporta além do comportamento habitual de sua idade, além de seu comportamento diário; no brinquedo é como se ela fosse maior do que é na realidade. Como no foco de uma lente de aumento, o brinquedo contém todas as tendências do desenvolvimento sob forma condensada, sendo ele mesmo, 
uma grande fonte de desenvolvimento (Vygotski, 1998, p.134-135). 


\section{CONSIDERAÇÕES FINAIS}

As escolas inclusivas devem reconhecer e responder às diversas necessidades de seus alunos, assegurando uma educação de qualidade a todos através do currículo apropriado, modificações organizacionais, estratégias de ensino, uso de recursos e parcerias com a comunidade.

A criança especial, ao ser inclusa deve ser acompanhada sistematicamente onde esteja, tendo à sua disposição condições pedagógicas, educacionais e terapêuticas para que ela aprenda algo, ou para que ela se integre com seus colegas com menos conflito e com mais segurança. Dentro das escolas inclusivas, as crianças com necessidades educacionais especiais devem receber qualquer apoio extra que possam precisar para que se lhes assegure uma educação efetiva.

Muitos documentos garantem esse direito, de uma escola digna, que atenda as necessidades dessa criança. Percebemos que alguns desses direitos ainda se encontram apenas nos papéis, mas muita coisa, mesmo a pequenos passos, tem sido feitas a fim de promover uma educação de qualidade. O envolvimento da escola, das famílias e da sociedade em geral fortalece o processo de inclusão, e os professores tem o papel de fortalecer uma inclusão digna no ambiente escolar.

Nas escolas um espaço que garante a preocupação e o envolvimento de forma mais direta com os alunos incluídos são as salas de recurso onde professores atendem no contra-turno, duas vezes por semana alunos incluídos. O objetivo dessa sala não tem nada a ver com reforço escolar, ela atende a criança nas suas necessidades, sejam elas cognitiva, afetiva, social e até motor; e promovem a inclusão dessas crianças em todo ambiente escolar.

O professor da sala de recurso utiliza como recurso pedagógico o lúdico por propiciar uma aprendizagem mais prazerosa, pois o brincar, por ser algo intrínseco a ela, propicia uma aprendizagem através do brincar onde ela estabelece formas de comunicação de vida comum com através da fantasia e imaginação

O lúdico é uma estratégia pedagógica essencial que propicia sensações novas que permitem explorar e desabrochar sentimentos e sentidos importantes inerentes ao homem, enfim a tudo que está envolvido em torno do desenvolvimento seja ele cognitivo, afetivo, social e motor. Sua utilização em trabalhos que envolvem expressão artística e jogos lúdicos, principalmente jogo simbólico, colabora no desenvolvimento 
de habilidades de comunicação, noção de limites, socialização, memorização e aquisição de conceitos e vocábulos.

O uso do lúdico através do jogo é tido como um rico instrumento pedagógico, mas só se tornará verdadeiramene rico quando percebe que a criança quando joga é um corpo dotado não só de um aspecto específico (motor) mas também o cognitivo, afetivo e social. Visto assim, ele deixa de ser um instrumento para ser condição básica para o desenvolvimento, valorizar o jogo é valorizar a iniciativa infantil; assim, oferecer um espaço de jogo, é também oferecer um espaço para descobertas permitindo aos alunos construir relacionamentos entre crianças e adultos tendo o jogo e as brincadeiras como um suporte de sociabilidade.

O que os alunos expressam é que o momento em que vivem o trabalho com o corpo e movimento eles expressam a sensação clara de liberdade de ação, espontaniedade e criatividade. Enquanto ser lúdico a criança que brinca encontra nesse espaço a oportunidade de ser ela mesma, com toda a sua essência desenvolvendo sua autonomia, capacidade de escolher e vencer situações problemas a criança.

A intervenção docente é uma forma de promover o desenvolvimento e ele pode utilizar como recurso a solução de situações problemas que vai ao encontro com o objetivo de favorecer o desenvolvimento da aprendizagem do aluno, ou seja, estimular a solução de situações problemas propostas e assim acaba promovendo uma relação entre o desenvolvimento social e cognitivo levando-as a refletirem e descobrirem novas ideias. Tal atitude faz desse professor um profissional comprometido com mudanças visto que os alunos não mais reproduzem os movimentos mais cria-os e socializa-os de forma criativia, espontânea e livre.

A pesquisa buscou perceber por meio de entrevista com professores de sala de recurso, como eles utilizam o lúdico como recurso pedagógico no processo de inclusão escolar de crianças especiais. Os professores em suas respostas demonstraram conhecimento sobre o processo de inclusão e como o trabalho direcionado as necessidades da criança favorecem seu desenvolvimento.

Os professores relataram em sua prática pedagógica que as atividades lúdicas são a base do seu trabalho na sala de recurso, e utilizam essa estratégia para alcançar todos os objetivos definidos para cada aluno na busca do desenvolvimento global da criança.

Quanto maior o estímulo recebido pela criança, maior a percepção atingida, qualquer que seja a sua modalidade. Ele se tornará uma pessoa feliz, mais completa, 
com melhores condições de lidar com o ambiente, viver em seu ambiente e obter maiores dimensões na aprendizagem e na vivência. A dimensão motora contribui com sua parcela para o desenvolvimento total e é, em si, a própria justificativa de sua inclusão no currículo (FLINCHUM, 1986). 


\section{REFERÊNCIAS BIBLIOGRÁFICAS}

ALMEIDA, Paulo Nunes de. Educação Lúdica: técnicas e jogos pedagógicos. São Paulo: Loyola, 1995.

ANGELUCCI, Carla Biancha. Uma inclusão nada especial: Apropriações da política de inclusão de pessoas com necessidades especiais na rede pública de educação fundamental do Estado de São Paulo. São Paulo, 2002. 171p. Dissertação de mestrado. Instituto de psicologia. USP.

AGUIAR, João Sarapião. Educação Inclusiva: Jogos para o Ensino de Conceitos. $2^{\text {a }}$ Ed. Sào Paulo: Ed. Papirus, 2005.

ARIÈS, Philippe. História Social da Criança e da Família. $2^{\mathrm{a}}$ ed. Rio de Janeiro: Ed. Guanabara, 1986.

\section{ARNAL, L. A PRÁTICA PEDAgógICA NAS SALAS DE RECURSOS.}

http://alb.com.br/arquivo-morto/edicoes_anteriores/anais16/sem09pdf/sm09ss02_06.pdf acessado em 07/12/2010.

ARRIBAS, Teresa Lleixà. Educação Física de 3 a 8 anos. $7^{\text {a }}$ Ed. Ed. Artmed, 2002.

BAUER, Martin W. \& GASKELL, George G. Pesquisa qualitativa com texto, imagem e som: um manual prático. $5^{\text {a }}$ ed. Rio de Janeiro: editora Vozes, 2000.

BELTRAMI, Dalva Maria. O JOGO COMO MEDIAÇÃO DO PROCESSO ENSINO APRENDIZAGEM EM CLAPAREDE. V.07, nº 01, p.19-23, Revista da Educação Física/ UEM, Paraná, 1997.

Boulch, Le. A Educação pelo Movimento. São Paulo: Editora Artes Médicas, 1983.

BRASIL. MEC. Lei de Diretrizes e Bases da Educação Nacional, LDB 9.394 de 20 de dezembro de 1996. 
BRASIL. Parâmetros Curriculares Nacionais. Brasília: MEC/SEF/SEESP, 1997. BROUGÈRE, Gilles . Jogo e educação. Porto Alegre: Artes Médicas, 1998.

CHATEAU, Jean. O Jogo e a Criança. Vol $294^{\text {a }}$ ed. São Paulo: Ed. Summus, 1987.

FLINCHUM, Betty M. Desenvolvimento Motor da Criança. Rio de Janeiro: Ed. Guanabara, 1986.

GIL, A.C. Métodos e técnicas de pesquisa social. São Paulo: Atlas, 1999.

GODOY, A. S. Introdução à pesquisa qualitativa e suas possibilidades. In: Revista de Administração de Empresas. São Paulo: v.35, n.2, p. 57-63, abril 1995.

MACHADO. Pré-Escola é não é escola: a busca de um caminho. Ed. Paz e Terra, Rio de Janeiro, 1991.

MARTINS, Lúcia de Araújo - et al. Inclusão: Compartilhando saberes. Rio de Janeiro: Ed. Vozes, 2006.

MENDES, Enicéia. A radicalização do debate sobre inclusão escolar no Brasil.Rev. Bras. Educ. vol.11 no.33 Rio de Janeiro Sept./Dec. 2006

PIAGET. Jean. A Formação do Símbolo na Criança. $2^{\mathrm{a}}$ ed. Rio de Janeiro: Zahar Editores, 1975.

PIAGET, Jean. O Julgamento Moral na Criança. São Paulo: Ed. Mestre Jou, 1977.

ROSAMILHA, Nelson. Psicologia do jogo e aprendizagem infantil. São Paulo: Ed. Pioneira, 1979.

Sala de recursos multifuncionais: espaços para atendimento educacional especializado. Secretaria de Educação Especial. Brasília: ME/SEE, 2006. 2 
SANTIN, Silvino. Educação Física : uma aborade filosófica da corporeidade. Ijuí: Ed. Unijuí, 1987, p. 63

STAINBACK, Susan \& STINBACK, William. Inclusão: um guia para Educadores. Porto Alegre: Artmed, 1999.

TRIVIÑOS, A. Introdução à pesquisa em ciências sociais: a pesquisa qualitativa em educação. São Paulo: Atlas, 1995.

VYGOTSKI, L. S. A Formação Social da Mente. 6 ${ }^{\text {a }}$ ed. São Paulo: Ed. Martins Fontes, 1998. 
APÊNDICES 


\section{APÊNDICE A \\ Roteiro de Entrevista Semiestruturada}

Idade:

Formação:

Tempo de docência:

Tempo de atuação junto aos alunos com NEE:

1- Como você concebe o processo de inclusão?

2- De que forma a sala de recurso tem atendido a criança especial?

3- Como a sua prática pedagógica acontece na sala de recurso de modo que contribua com a inclusão?

4- Qual a sua opinião sobre o lúdico no processo de ensino-aprendizagem?

5- A atividade lúdica é um dos objetivos do seu planejamento? Sua escola propicia espaços e materiais adequados para se trabalhar o lúdico na sala de recurso?

6- Qual a relação que pode ser estabelecida entre o aspecto pedagógico das atividades lúdicas e o processo de inclusão?

7- Quais os ganhos de ordem: cognitivo, afetivo, social e motor você observa quando utiliza o lúdico na sala de recurso?

8- O que é mais perceptível quando as atividades lúdicas acontecem de forma:

Livre:

Em grupo:

Individual:

9- Cite 3 principais objetivos, em sua prática pedagógica, que você deseja alcançar com seus alunos incluídos quando trabalha em grupo utilizando as atividades lúdicas?

10-Quais são as atividades lúdicas mais utilizadas e que benefício acha que elas trazem? 
11-As crianças costumam propor atividades?

( ) Não

( ) Sim. Quais? Em que momentos? 
ANEXOS 


\section{ANEXO A \\ CARTA DE APRESENTAÇÃO}

A(o) Diretor(a) da Escola

De: Profa. Dra. Diva Albuquerque Maciel

Coordenadora Geral do Curso de Especialização em Desenvolvimento Humano, Educação e Inclusão Escolar

\section{Assunto: Coleta de Dados para Monografia}

Senhor (a), Diretor (a),

A Universidade Aberta do Brasil - Universidade de Brasília está em processo de realização da $1^{\text {a }}$ oferta do curso de Epecialização em Desenvolvimento Humano, Educação e Inclusão Escolar, do qual seis dentre as 20 turmas ofertadas são de professores e educadores da rede pública do DF (polos UAB-UnB de Santa Maria e Ceilandia). Finalizamos agora a $1^{\text {a }}$ fase do curso e estamos iniciando a Orientação de Monografia.

É requisito parcial para a conclusão do curso, a realização de um estudo empírico sobre tema acerca da inclusão no contexto escolar, cujas estratégias metodólgicas podem envolver: entrevista com colegas, pais ou outros participantes; observação; e análise documental.

A realização desses trabalhos tem como objetivo a formação continuada dos professores/servidores da rede pública, subsidiando-os no desenvolvimento de uma prática pedagógica refletida e transformadora, tendo como consequência uma educação inclusiva.

O trabalho, a ser desenvolvido na escola sob sua direção, será realizado pelo Professor/cursista Mara Jhosy Paula Queiroz, cujo tema de pesquisa é: "O uso pedagógico do Lúdico no processo de inclusão escolar da criança especial", sob orientação da profa. Rute Nogueira de Morais Bicalho. 
Desde já agradeço, colocando-me a disposição de Vossa Senhoria para maiores esclarecimentos nos telefones. (061 8114-2995) ou por meio do e-mail: arutebicalho@gmail.com

Atenciosamente,

\section{Diva Albuquerque Maciel}

Coordenadora Geral do Curso de Especialização em Desenvolvimento Humano,

Educação e Inclusão Escolar 


\section{ANEXO B \\ TERMO DE CONSENTIMENTO LIVRE E ESCLARECIDO}

Senhores Professores,

Sou orientanda do Curso de Especialização em Desenvolvimento Humano, Educação e Inclusão Escolar, realizado pelo Instituto de Psicologia por meio da Universidade Aberta do Brasil- Universidade de Brasília (UAB-UnB) e estou realizando um estudo sobre "O uso pedagógico do lúdico no processo de inclusão escolar da criança especial". Este estudo poderá fornecer às instituições de ensino subsídios para o planejamento de atividades com vistas à promoção de condições favoráveis ao pleno desenvolvimento dos alunos em contextos inclusivos e, ainda, favorecer o processo de formação continuada dos professores nesse contexto de ensino.

Constam da pesquisa entrevistas (gravadas em áudio) com os educadores. Para isso, solicito sua autorização para participação no estudo.

Esclareço que a participação no estudo é voluntária. Você poderá deixar a pesquisa a qualquer momento que desejar e isso não acarretará qualquer prejuízo a você. Asseguro-lhe que sua identificação não será divulgada em hipótese alguma e que os dados obtidos serão mantidos em total sigilo, sendo analisados coletivamente.

Caso tenha alguma dúvida sobre o estudo, o(a) senhor(a) poderá me contatar pelo telefone 3581-3711 ou no endereço eletrônico marajpq@hotmail.com. Se tiver interesse em conhecer os resultados desta pesquisa, por favor, indique um e-mail de contato.

Agradeço antecipadamente sua atenção e colaboração.

Respeitosamente,

Orientando Mara Jhosy Paula Queiroz (UAB - UnB) 
Concorda em participar do estudo? ( ) Sim ( ) Não

Nome:

Assinatura:

E-mail (opcional): 